\title{
Strengthening the Development of State Defense Resources and Building the National Logistic Reserves
}

\author{
Novky Asmoro, Mitro Prihantoro, Iqbal Fikri \\ Doctoral Program of Defense Studies, Republic of Indonesia Defense University, Bogor, Indonesia \\ Email address: \\ novky.asmoro@idu.ac.id (N. Asmoro), mitro.prihantoro@idu.ac.id (M. Prihantoro), iqbal.fikri@idu.ac.id(I. Fikri)
}

To cite this article:

Novky Asmoro, Mitro Prihantoro, Iqbal Fikri. Strengthening the Development of State Defense Resources and Building the National Logistic Reserves. Science, Technology \& Public Policy. Vol. 5, No. 1, 2021, pp. 54-59. doi: 10.11648/j.stpp.20210501.16

Received: April 10,2021; Accepted: April 26, 2021; Published: May 8, 2021

\begin{abstract}
National resources for national defense in principle include human resources, natural resources, artificial resources and national infrastructure for national defense. The existence of resources and infrastructure will be a systematic implementation of development programs if proactive citizens support and participate in defense efforts of the state as well as in supporting the construction of national logistics reserves. SWOT analysis is used in addition to seeing the red thread between the two problems, also determining both internal and external factors for effective extraction strategies. Through a combination of comprehensive study literature and library research, it is hoped that analysis will lead to discrete efforts involving government programs in embody one of these 2021 state defense policies. The interplay of resources, the use of methods to determine the correct strategy goals is believed to direct the strategy to the right programs. The results of this study, internal factors in the strategic perspective can be elaborated with several external factors, namely the Opportunity aspect, namely the stability of stable civil-military relations, the potential for Natural Resources \& Artificial Resources and the availability of Sarpras and Infrastructure as well as threats including high law violations, terrorism and radicalism and primordialism which are still high. These efforts are optimized to produce a solution strategy in solving the problem of developing defense resources and building national logistical reserves. The strategy determined based on SWOT calculations and weighting is in Quadrant I which means a favorable situation so that the strategy implemented is to fully support government policy.
\end{abstract}

Keywords: Defense Resources, National Logistics Reserve, SWOT Analysis, State Defense Policy, Strategy

\section{Introduction}

The national resource preparation strategy for any worthwhile defense must be based on a paradigm of nationalism. It is hoped that the growing sense of nationalism will take every Indonesian citizen, including the leaders, and are actively involved in every defense of the state. When it is attributed to human resources, national defense perspectives should try to instill nationalistic values as a component of the development of defense resources. The introduction of the national resources strategy for national defense on the basis of its national soul will be realized if any concrete action is carried out, the two things of Indonesian pride and comprehensive insight into the state's defense system. What an irony that the national education system is so poor it teaches the values of patriotism and nation. Exemplary values on the struggle of marginalized heroes requires effort to recultivate pride in youth segments of Indonesians.

Understanding of comprehensive patriotism and nationalism also cannot be unleashed on efforts to manage natural resources, artificial resources and infrastructure to support the state's defenses. Patriotism is not the same as nationalism. It means a love of one's native country and a willingness to sacrifice oneself to defend it, but it need not invoke the idea of a self-conscious nation discussed nor need it imply that the country in question should enjoy political self-determination [1]. Nationalistic values that teach patriotism and love of the fatherland will trigger any resource management and infrastructure administration presenting its best work through strong national logistics reserves. Therefore, for the organization of the various resources and infrastructure to be applied tactical in support of national defenses, efforts are needed to dig up and analyze the apay that is a factor in strengths, weaknesses, opportunities, and 
threats. It is hoped that accurate analysis will enable better defense resource preparation strategies.

\section{Defense Resource Consolidation Strategy}

Existing strategies in defense science are linked to a reflection of how countries behave to maintain and develop their own sustainability. Thus, the building of agricultural resources functions encode all aspects of security on a national scale attached to the country's defense agenda [2]. As strategy theory dictates that "a coherent expression of a process that identifies the ends, ways, and means designed to achieve a certain goal. Mathematically, we might express this as "Strategy = Ends + Ways + Means." Ends are the objectives or desired outcomes of a given strategy. The term end-state is synonymous with ends. An end or ends comprise the goal of the strategy. Ways are actions". [3]

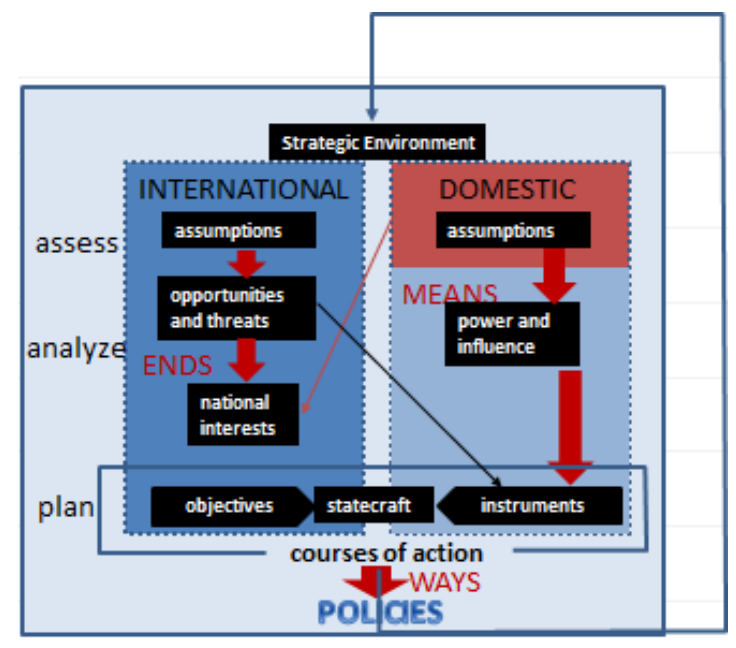

Source: Deibel (2007), Foreign Affair Strategies

Figure 1. Implementation of strategy in the policymaking process.

If disassembled, "strategy" is particularly needed to determine the process of strengthening defense resource building functions by means of means or methods (Ways) From the state to safeguard and develop a defense of the country with the management of its own national resources (Means) In order to achieve national interests (Ends). The national resources here include human resources, natural resources, real good artificial resources (tangible) Nor real (intangible) As well as infrastructure toward the defense of the state [4].

In order to do that, Indonesia would not be able to do so, he said. This in principle requires enhanced governance through systematic programs in order to achieve what the nation wants. A constructive and continuous strategy, with legalizing support or directional rules, will achieve sustainability in spite of the change in the government's era. On the aspect of human resources, the state's defense system will be properly implemented if there is harmony in any effort to implementa strategy related to its coaching function
[5]. Illustrative defense resources strategies can be seen in the chart above.

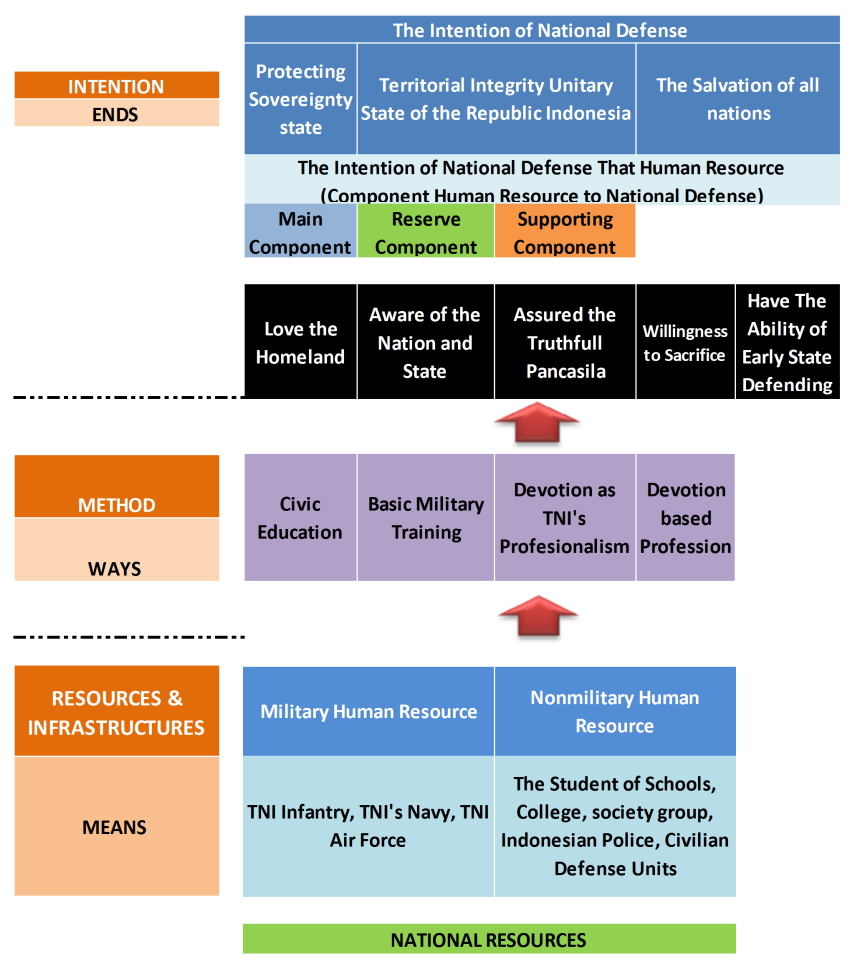

Figure 2. Human resources defense strategy concept.

Source: Asmoro (2016), The strategy and challenges of the human resources defense nation

\section{Development of National Logistics Reserves}

As noted in the 2020 state defense doctrine, the threat is known to consist of military, non-military and hybrid threats [6]. Of some forms of nonmilitary threats that are potentially destabilizing the fabric of a country's life, one is the threat of a food crisis. According to what the President has quoted from warnings from the United Nations food and agriculture organization (FAO) that there is a potential global food crisis that could happen at any time, at the time creation of the covid 19 pandemic, or the crisis caused by other factors. Therefore, it is expected at an early date to avoid a food crisis.

Reporting from the ministry of defense's official website, three things are the focus of restructurization in the construction of National Logistics Reserves, the structurization of regional logistics and the establishment of space logistics for Indonesia's food reserves and cooperation with some in support of the national food security program [7]. Food security programs as part of the national logistics reserves effort are developed as a government effort to: (1) As the food supply center of state-owned land, (2) As reserve through the management of food reserves for the state defense, (3) The government's efforts to provide food reserves throughout Indonesia. 
According to the 2019 year law on National Resource Management for National Defense, these management must be capable of directing existing human resources through the power of the key components, reservoles and components. This condition is further strengthened when the principles in the national logistics system in accordance with Presidential Decree No. 26/2012 concerning the Blueprint for the Development of the National Logistics System need to be accommodated in efforts to develop national logistics reserves so that the logistics managed can be properly distributed when the country faces a crisis situation [8].

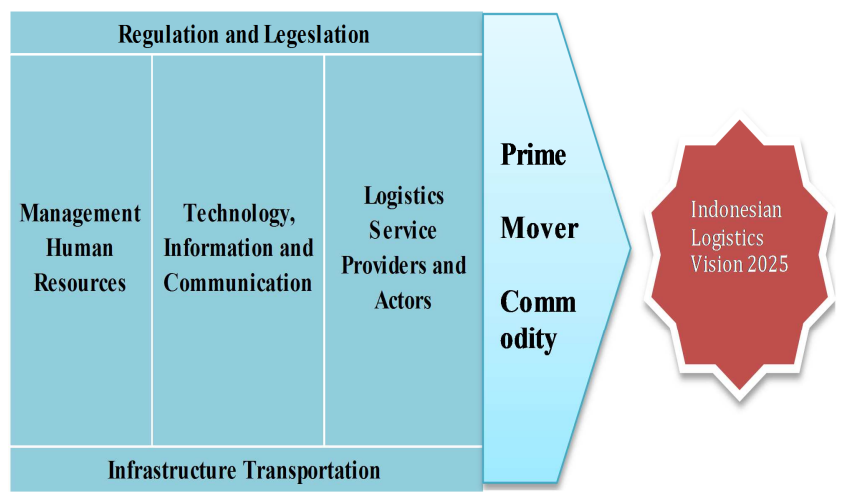

Figure 3. The driving factor of the national logistics system.

Source: Presidential Decree Number 26 of 2012, The blueprint for the development of the national logistics system

To organize the construction of the national logistics reserves, it needs a holistic understanding of the actors who play their part. Insufficient natural and artificial resources and supporting infrastructure is not enough to ensure that national logistics reserves are capable of distributing especially in emergencies or wars that require high mobilization. Factors based on the drive of the national logistical system are reference to a comprehensive strategy based on the swot analysis that follows.

\section{SWOT Analysis}

SWOT analysis is a useful strategy planning technique to evaluate strengths and weaknesses, opportunities, and threats on a project. It also comes down to a sample of SWOT analysis for the company [9]. But certainly, both an analysis of an ongoing project and a new one. SWOT Analysis is an analysis method used to evaluate the 'strengths', 'weaknesses', 'opportunities' and 'threats' involved in an organization, a plan, a project, a person or a business activity. In this qualitative and descriptive study, firstly the position of SWOT Analysis in the strategic management process is explained, secondly the components of SWOT Analysis is examined [10].

The SWOT analysis method is an appropriate tool for finding the problem of 4 (four) different sides, where the application is: (1) How power can take advantage of the opportunities there is, (2) How can we overcome the weaknesses that prevent profit, (3) How power can take advantage of an opportunity that exists, (4) How to overcome weaknesses that can make threats real or create new ones.

By interconnecting the 4 factors, thus making this analysis possible makes it easier to realize the organizational vision and mission or strategic goals of a particular program.

The SWOT analysis is elaborated as an attempt to elaborate out the factors that influence a program so as to have an effective chance of achieving both internal factors of strength and weakness and of external factors that cover opportunities and threats.

\section{Internal Factors Empowerment}

The state's principle of defense in 2021, which specifically established the development of national defense and logistics reserve, is a strong state commitment to improving the more comprehensive defense systems. In harmony with the theory parameters for the destiny of a nation influenced by geography, demographics and history, then internal factors as forces (strength) will lead to the development of dominant defense resources in the existence of human resources in addition to existing political and governmental systems.

Such a large population, when it is empowered as a source of defense, will have a pervasive sense of civic consciousness to create a conducive atmosphere across the country. Citizen consciousness will lead to a strong state of defense to enable the economic wheel and development of countries to run under the stability of established state security and no more communal conflicts or national disintegration efforts [11].

Indonesia's growing population in 2020 will reach 270 million, bringing its own strength from internal factors. Strength is enhanced when a demographic bonus comes early. The rapid growth in the number of people of the working age is occurring faster than government estimates. By September 2020, the population ages of 15-64 has reached $70.7 \%$ of Indonesia's total or about 191 million [12]. Actually demographic bonuses are not viewed only in terms of meeting the needs of labor force at a purely productive age. Potential citizens of that age will be able to stimulus in other areas, including political life in democracy and openness. The approval of the no. 23 on the management of national resources is evidence that an opening of a political perspective of a nation that no longer views the bill as being full of militaristic [13]. On the other hand, the reality that state's defense values include programs designed by governments has not been pervasive in society because of an equally less than optimal share of education. It will be weaknesses over itself when governments try to encourage the building of defense resources. Human resources with proper enlightenment on the state's defense values are expected to be able to print the intellectual state as a spearhead in the implementation of its defense values. It is hoped that with the intellectual level of the state's defenses, it is being operated by experts who not only have the capabilities as a conceptor but are able to implement them precisely on citizen conditions. 


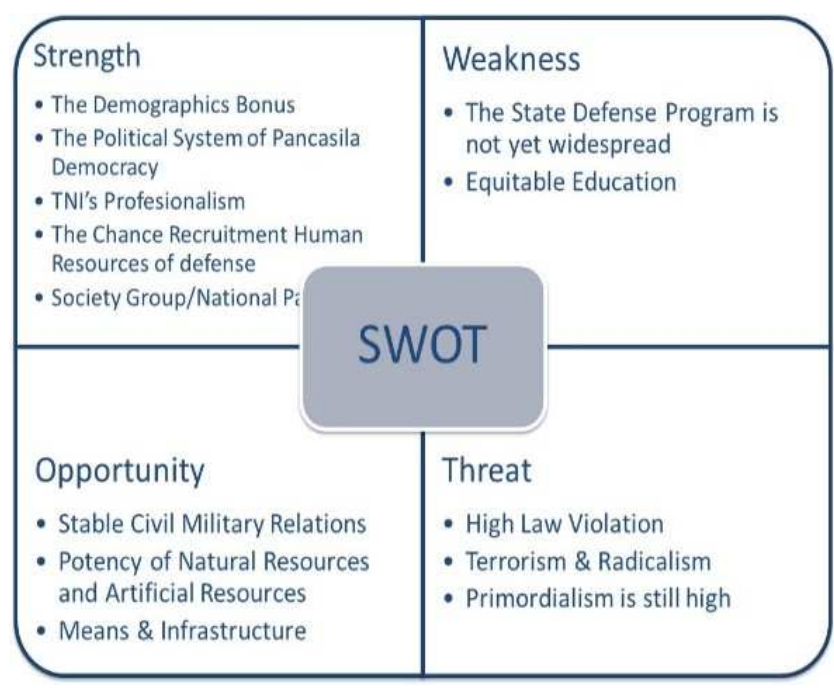

Figure 4. Matrix SWOT.

\section{External Factors Empowerment}

Simultaneous with the strategy for empowering human resources national defense, and the challenges and obstacles faced are no less massive. The most obvious challenge, the socialization of nationalism and the country's sense of defense, is hampered by uneven economic and citizen education. The biggest obstacle is the slow process of legislation on national defense systems as legal umbrellas in legitimizing the efforts of the nation's defense powers in the state's system of government. That is important because it has a strong correlation of how the mechanisms of civil and military relations can be formed.

The certainty of a legal formal aspect will be a unique opportunity for the enabling of the entire defense resources to be able to be deployed both as a primary component, a reserve and supporting component especially when countries face a crisis and war that requires mobilization efforts [14]. They also provide opportunities for the overall dimension of national resources potential through adequate tools and infrastructure. Such a situation is a fine opportunity when the synergy of all the components of the state's defense system is able to run without any secretion of sectorial egos still found to this day.

Indoensia as the island nation is currently transitioning from an agricultural economy driven by commodity exports to an economy based on industrial manufacturing and services [15]. Despite the poor economy and education of the nation, the radicalism, the high levels of lawlessness and primordialism are threats that are still worrying about today. Economic inequality and high poverty resulting from the pandemic covid-19 that generate a potential economic crisis, making people more concerned about meeting the needs of life. They feel that there must be an effort to solve the problem and that, ironically, it is a factor that triggers rate of law.

Criminal diversity also demonstrates an increasing trend, including social friction and communal conflict in communities. The situation posed a significant threat when riots occurred against the interior of Sara, identity politics and other horizontal conflicts still rage. A sight that is both a real threat when national programs and defense and united slogans are also massively promoted by governments in various media.

\section{Strategy and Solution}

The use of analysis SWOT as explained earlier that in addition to being able to identify key factors affecting a problem, it is also a reference to the strategy in solving the problem. On the basis of expert advice, study literature and library research, the whole problem has been identified. Housekeeping and calculations will be presented as follows:

SWOT analysis above is calculated according to the weight score of any problems that arise in all aspects Strength, Weaknesses, Opportunity and Threat. Examinations and scoring had been validated with some secondary data obtained from various sources based on study literature and library research and thus produced appropriate choices or strategies. A quadrant of strategy based on the SWOT analysis calculations is as follows:

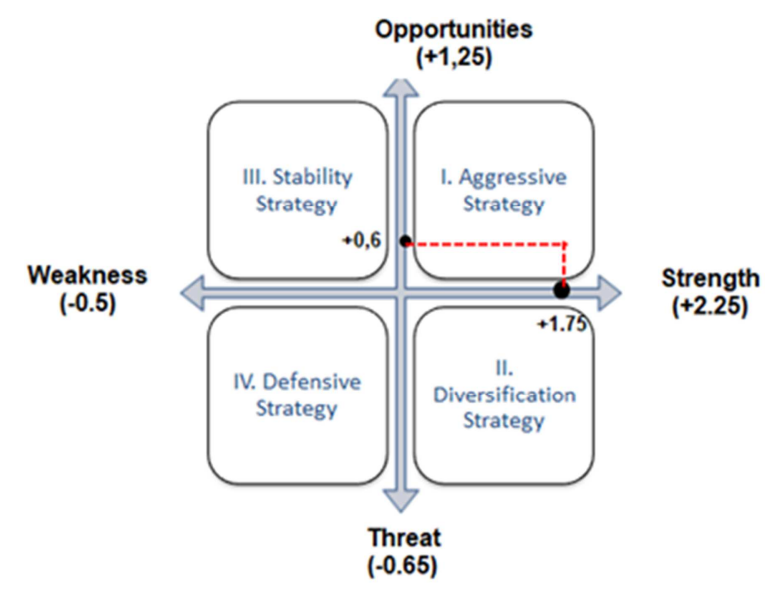

Figure 5. Internal and External Factor Calculation Matrix.

To clarify which section an idea belongs to, it may be useful to think of Strengths and Weaknesses as internal factors - that is, to do with the organization. Think of Opportunities and Threats as external factors, arising from the market, competition, and the wider community [16]. SWOT analysis shows that the strategy to be chosen is in quadrant I means the strategy will be in a very favorable situation. The strategy is in full support of government policies with its programs for strengthening the defense efficiency and building national logistics reserves. Specifically the solutions that need to be implemented among them: (1) How are the strengths of the demographics bonus, the political system of Pancasila (Five Principle Value of Indonesia) democracy, the Indonesia Armed Forces (TNI) professionalism, the opportunities of resources defense, society group and party nationalist opportunities to take advantage of the opportunities available. The condition has been stable and the improvement of military relations, Nature Resources \& Artificial Resources potential, get response to recruitment human resource for defense dan organize 
national reserve logistics related human resource, regulations, technology information and transportation system (2) Government strategies need to determine (Ends), methods (Ways) and resources (Means) in dealing with weaknesses (Weaknesses) are not, among other things, the pervasive system of state defense and education. One illustration of when a strong sense of defense is embedded, implementing it is of high professional value. It would encourage total professional devotion so that effective building of defense resources and preparation of the national logistics reserve could be achieved, (3) The aspect of the power of the demographics bonus, the political system of Pancasila democracy, the TNI's professionalism, the opportunities of recruits to hand human beings and Natural Resources and
Artifical Resources nationalist to counter threats from high lawlessness, terrorism \& radicalism and primitive growth. The combination of the TNI's professionalism and the provision of the human resources supported by the democratic climate and the Pancasila political system is expected to erode distortion, sentiment, and increase legal consciousness in society, (4) Various (Weaknesses) Among other things, there is no way for a country's defense program to develop and the education that remains, there is a growing sense of radicalism at the foundation of terrorism. In addition, such weakness will encourage increased awareness of the law, fudging the level of lawlessness and the easier public is to be divided when faced with Sarah's issues.

Table 1. Weighted and Calculation Internal and External Factor of SWOT.

\begin{tabular}{|c|c|c|c|}
\hline INTERNAL STRATEGY FACTORS & (WEIGHTED) & (RATING) & WEIGHT SCORE \\
\hline \multicolumn{4}{|l|}{ STRENGTH } \\
\hline The Demographics Bonus & 0.2 & 4 & 0.8 \\
\hline The Political System of Pancasila Democracy & 0.15 & 3 & 0.45 \\
\hline TNI's Profesionalism & 0.15 & 4 & 0.6 \\
\hline The Chance Recruitment Human Resources of defense & 0.1 & 2 & 0.2 \\
\hline Society Group/National Party & 0.05 & 4 & 0.2 \\
\hline Sub Total & 0.65 & & 2.25 \\
\hline \multicolumn{4}{|l|}{ WEAKNESESS } \\
\hline The State Defense Program is not yet widespread & 0.2 & 1 & 0.2 \\
\hline Equitable Education & 0.15 & 2 & 0.3 \\
\hline Sub Total & 0.35 & & 0.5 \\
\hline Score Total & 1 & & 2.75 \\
\hline \multicolumn{4}{|l|}{ OPPORTUNITIES } \\
\hline Stable Civil Military Relations & 0.15 & 3 & 0.45 \\
\hline Potency of Natural Resources and Artificial Resources & 0.2 & 4 & 0.8 \\
\hline Means \& Infrastructure & 0.15 & 3 & 0.45 \\
\hline Sub Total & 0.5 & & 1.7 \\
\hline \multicolumn{4}{|l|}{ THREATS } \\
\hline High Law Violation & 0.15 & 1 & 0.15 \\
\hline Terrorism \& Radicalism & 0.15 & 2 & 0.3 \\
\hline Primordialism is still high & 0.2 & 1 & 0.2 \\
\hline Sub Total & 0.5 & & 0.65 \\
\hline Score Total & 1 & & 2.35 \\
\hline
\end{tabular}

\section{Conclusion}

Based on SWOT's analysis and calculations, it can be deduced from a strategy for strengthening the defense efficiency function and building national logistics reserves, among other things: (1) The internal factor is an aspect of force (Strengths) Include Demographic Bonus, the political system of Pancasila democracy, the TNI's professionalism, the opportunities of the recruitment of human resources hand and Society Group and Party nationalist and aspects of (Weakness) They include the deployment of national defense programs and the equality of education. The internal factors at the perspective of the strategy are elaborated with some external factors, the aspects of the opportunity of stable military civilian relations, the potential of Natural and Artificial Resources and the availability of Sarpras \& infrastructure and (Threat) Among the high incidence of lawlessness, approval of terrorism and radicalism. Such efforts are optimized to provide solutions to the problem of developing defense resources and developing national logistic reserves. (2) The strategies determined by calculations and the SWOT administration are in quadrant I, which is a favorable situation and therefore the applicable strategy is in full support of government policies. Concrete programs for improving the functionality of defense resources are available to optimize human resources, the development of legalistic and planning aspects and the management of natural and artificial resources. Meanwhile, the development of national logistics reserves is more focused on the sector of regulatory compliance, human resources, and information technology systems for players and logistics service providers and transportation infrastructure.

\section{References}

[1] Routledge Encylopedia of Philisophy, The Evolution of Nationalism, https://www.rep.routledge.com, retrieved on April 10, 2021. 
[2] Tippe, Syarifudin (2017). Ilmu Pertahanan: Sejarah, Konsep, Teori dan Implementasi, Penerbit Salemba Humanika.

[3] Lykke Jr. Arthur F. (1998). Military Strategy: Theory and Application Carlisle, PA: U.S. Army War College.

[4] Deibel, Terry L (2014). Foreign Affairs Strategy Logic for American Statecraft, Cambridge University Press.

[5] Asmoro, Novky (2016). Strategi dan Tantangan Pengembangan Sumber Daya Manusia Pertahanan Negara, Majalah Wira Kemhan Edisi 2016, Puskompublik Kementerian Pertahanan RI.

[6] Kemhan RI (2014). Buku Putuh Pertahanan Indonesia, Indonesian Defense White Paper, Permenhan RI Nomor 54 tahun 2014

[7] Kemhan RI, Kemhan Terus Wujudkan Cadangan Logistik Strategis Nasional, www.kemhan.go.id, diakses 3 April 2021.

[8] Perpres Nomor 26 tahun 2012 tentang Cetak Biru Pengembangan Sistem Logistik Nasional, https://peraturan.bkpm.go.id., diakses 3 April 2021.

[9] Humphrey, Albert (2005). SWOT Analysis for Management Consulting, SRI Alumni Newsletter. SRI International.
[10] Guret, Emet (2017). SWOT Analysis: A Theoretical Review, Journal of International Social Research 10 (51): 994-1006.

[11] Department for International Development (2010). The Politics of Poverty: Elites, Citizens and States A Synthesis Paper Findings from ten years of DFID-funded research on Governance and Fragile States 2001-2010, Centre for the Future States.

[12] Dorimulu, Primus (2021). Indonesia Sedang Menikmati Bonus Demografi, https://www.beritasatu.com, diakses 30 Maret 2021.

[13] JDIH BPK RI (2019). Undang-undang (UU) Nomor 23 Tahun 2019 tentang Pengelolaan Sumber Daya Nasional Untuk Pertahanan Negara, Database Peraturan.

[14] State Ministry of National Development Planning/ National Development Planning Agency (2005). Law of The Republic of Indonesia Number 17 of 2007 On Long-Term National Development Plan of 2005-2025, Bappenas RI.

[15] Dillas, et. al (2019). Education in Indonesia, Education System Profiles, World Education News + Reviews.

[16] Mind Tools (2021). SWOT Analysis How to Develop a Strategy For Success, https://www.mindtools.com, Retrieved on April 10, 2021. 